\title{
PRODUCTION OF A BIOLUBRICANT BY ENZYMATIC ESTERIFICATION: POSSIBLE SYNERGISM BETWEEN IONIC LIQUID AND ENZYME
}

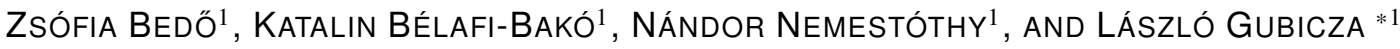 \\ ${ }^{1}$ Research Institute of Bioengineering, Membrane Technology and Energetics, University of Pannonia, \\ Egyetem u. 10, Veszprém, 8200, HUNGARY
}

\begin{abstract}
The possible replacement of lubricants with fossil-fuel sources and the manufacture of biolubricants with more beneficial features were studied. Oleic acid and isoamyl alcohol were reacted with an enzyme in an ionic liquid. During the reaction conventional as well as microwave heating was applied. After the experimental determination of the optimal reaction parameters, it was unexpectedly found that a synergistic effect occurred by applying ionic-liquid and microwave-heat treatment simultaneously. The enzyme exhibited a much higher level of activity than the value expected based on the measurements carried out separately by using an ionic liquid instead of an organic solvent and microwave-heat treatment or a conventional method. In the experiments with recycled enzyme it was found that ionic liquid maintained the enzyme more effectively, as if it was immobilized by it: the enzyme managed to maintain its activity and recycling ability.
\end{abstract}

Keywords: synergistic effect, ionic liquid and microwave heating, biolubricant production, enzyme reuse

\section{Introduction}

Lubricants from mineral oils have a considerable detrimental effect on the environment due to the aromatic organic compounds within their chemical structures. Mineral oils that have leached into water or soil are toxic for living organisms, they substantially decrease the level of dissolved oxygen in the water. These lubricants can hardly be degraded biologically. During their manufacture several by-products form and further additives are needed for the lubricants. Hence the demand for biolubricants from plant oils has been growing recently, since they are natural, renewable, non-toxic as well as environmentally-friendly compounds, and often cheaper than synthetic oils. Therefore, they are suitable for eliminating the disadvantages of mineral oil, moreover, our dependence on mineral oils and other non-renewable sources might be decreased [1,2].

The production of synthetic and semi-synthetic lubricants is necessary since now it is not possible to conduct all lubrication tasks by using lubricants derived exclusively from mineral oils. In several cases non-coking lubricants with extremely high degrees of viscosity are able to operate at low temperatures (below $-50{ }^{\circ} \mathrm{C}$ ). Biolubricants are used in numerous fields of application, but in all of them it is vital to prevent the contamination (only a negligible level is acceptable) of the product and environment. These provide an alternative to the mineral oilbased lubricants in industrial applications that are used in

\footnotetext{
*Correspondence: peter.troska@uniba.sk
}

the automotive industry as hydraulic fluids during metal processing and oils for driving gears [3]. They are not considered as biological hazards in water systems when applied in watercrafts.

In biotechnological methods for the manufacture of biolubricants, raw materials with a high oleic acid content are generally used for the transesterification processes. Biolubricants are mainly produced from plant oils, e.g. sunflower oil, soybean oil and castor oil $[4,5]$. The lifetime of these biolubricants that possess esters is usually longer than those obtained from mineral oils. On the other hand, their widespread industrial usage is hindered by the fact that certain equipment must be converted to run on biolubricants [6].

Various esters can be enzymatically produced from acids and alcohols of different chain lengths in nonconventional systems (organic solvents, ionic liquids, supercritical fluids, solvent-free media). Thus, the esterification of acids and alcohols of short chain lengths by lipase results in flavour esters [7,8]. The esterification of fatty acids (acids with carbon numbers of between 12 and 18) and alcohols may yield both biolubricants and biofuels depending on alcohols' chain lengths $[9,10]$. Biodiesel is obtained when alcohols of short chain lengths are used, while biolubricants can be manufactured by alcohols of long chain lengths.

The formation of a biolubricant from oleic acid and isoamyl alcohol in organic solvents has been studied previously [11-13]. The term 'biolubricant' may be used since both isoamyl alcohol and oleic acid are considered 
to occur naturally and the reaction is carried out by a naturally-occurring catalyst, an enzyme. Koszorz et al. studied the same reaction and stated that the water formed as a by-product of the esterification reaction had a negative effect on the rate of reaction and activity of the enzyme. To enhance the effectiveness of the process, water had to be removed by an integrated system where the reaction was combined with a pervaporation unit [14].

Turkish researchers applied fusel oil - a by-product of bioethanol production - containing a significant amount of isoamyl alcohol that was used to synthesize a biolubricant with high yield [15].

In addition to organic solvents, good results were achieved recently using ionic liquids as solvents. In the field of heat treatment microwave irradiation has yielded excellent results in both organic synthetic and enzymatic reactions $[16,17]$. In transesterification reactions even a synergy effect was observed between the enzyme and ionic liquid [18-20].

The aim of this paper was twofold: (i) to study the possibility of applying ionic liquids instead of organic solvents; (ii) to investigate the role of microwave irradiation to achieve the highest possible degree of conversion in the minimum amount of time.

\section{Experimental}

The reactions were conducted in an incubator shaker and microwave equipment using conventional heating and microwave irradiation, respectively. Similar compositions and reaction volumes were used in the measurements to be able to compare the experimental results.

\subsection{Samples and Measurements}

All chemicals were commercially available and used without further purification.

Novozym 435 (immobilised Candida antarctica lipase B, CALB), a triacylglycerol acylhydrolase (E.C. 3.1.1.3.) immobilized on an acrylic resin, was a gift from Novozymes (Bagsvćrd, Denmark). Its nominal catalytic activity and water content were 7000 propyl laurate units (PLU)/g and 1-2\%, respectively. Isoamyl alcohol (98\%) and oleic acid (99\%) were used as received from SigmaAldrich. The ionic liquid 1-butyl-3-methylimidazolium hexafluorophosphate $\left([\mathrm{bmim}] \mathrm{PF}_{6}\right)(\geq 98.5 \%)$ was purchased from Sigma-Aldrich while n-hexane and isooctane $(99 \%)$ were acquired from Reanal.

To follow the yield of the ester, a HP-5890A gas chromatograph (GC) was used. The device was equipped with a split/splitless injector, flame ionization detector (FID), and DB-FFAP column (length: $10 \mathrm{~m}$, inner diameter: 0.53 $\mathrm{mm}$, film thickness: $1.00 \mu \mathrm{m})$. The following heating programme was applied: $130{ }^{\circ} \mathrm{C}, 3$ mins.; temperature ramp up: $10^{\circ} \mathrm{C} \min ^{-1} ; 240{ }^{\circ} \mathrm{C}, 5$ mins. Isooctane was used as an internal standard. For the analysis, a $10 \mu \mathrm{L}$ sample of the reaction mixture was extracted.
Reaction mixtures that contain ionic liquids cannot be injected into the GC, since they - as a viscous liquid form a deposit on the inner side of the column that causes fouling. Moreover, they may be degraded due to the high temperature, thus, the precision of the measurements will be affected and undesirable peaks may appear in the chromatograms. During the measurements the components are usually separated from the ionic liquid by extraction and injected into the column.

In our measurements - to preserve the GC column - fiberglass and adsorbent material were placed inside the injector, which retained the ionic liquid after injection while the component to be analysed was transferred in a gas phase to the column as a result of the high temperature. In this way extraction of the product from the reaction mixture could be avoided, therefore, the errors that originate from the incomplete extraction (effectiveness) could be eliminated.

\subsection{Experimental setups}

Two different procedures were used for the production of biolubricants. Firstly, by using conventional heating the synthesis of biolubricants was conducted in Eppendorf tubes $(1.5 \mathrm{~mL})$ at $40{ }^{\circ} \mathrm{C}$ rotated at $200 \mathrm{rpm}$ (IKA incubator shaker KS 4000i). In a typical experiment $5 \mathrm{~cm}^{3}$ of reaction mixture $(22.5 \mathrm{mmol}$ of isoamyl alcohol and 3.75 mmol of oleic acid dissolved in n-hexane or [bmim] $\mathrm{PF}_{6}$ ) was prepared in a volumetric flask, and the Eppendorf tubes were each filled with $1 \mathrm{~cm}^{3}$ of the reaction mixture. The reaction started when $10 \mathrm{mg}$ of the enzyme was added.

Tests under microwave conditions were performed in a commercial microwave synthesizer (Discover series, BenchMate model, CEM Corporation, USA). It was equipped with a magnetic stirrer and a fibre-optic sensor to monitor the temperature, which was set by varying the power of the microwave. For the esterification of biolubricant, $10 \mathrm{~W}$ of energy was used to maintain the temperature of the reaction between 40 and $60{ }^{\circ} \mathrm{C}$. The volume and composition of the reaction mixture was identical to under conventional conditions.

Experiments to study the reusability of enzymes were conducted by separating the enzyme from the reaction mixture and starting a novel reaction with a reaction mixture of the same volume.

\section{Results and Analysis}

\subsection{Experiments}

Certain ionic liquids may catalyse esterification reactions. Even though in the case of $[\mathrm{bmim}] \mathrm{PF}_{6}$ this phenomenon does not occur according to earlier publications, measurements were conducted in reaction mixtures which did not contain enzymes to be able to exclude this effect. Our experiments confirmed previous results from the literature: $[\mathrm{bmim}] \mathrm{PF}_{6}$ did not catalyse the reactions. 


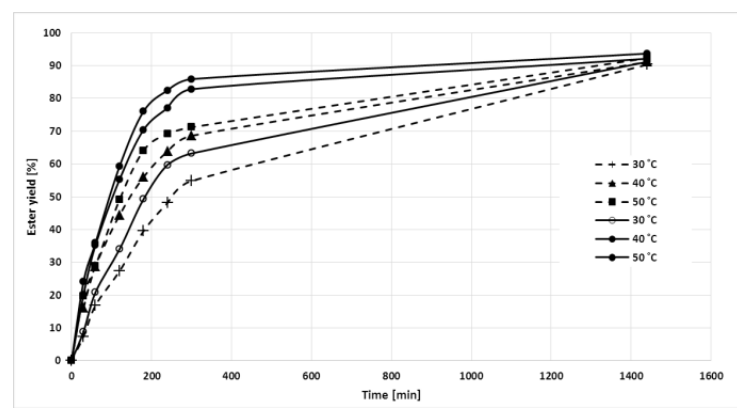

Figure 1: Biolubricant production in the organic solvent (dashed lines) and ionic liquid (solid lines) using conventional heating.

The experimental conditions were selected according to data from the literature in addition to our earlier observations, and they were checked by preliminary measurements. Thus, the molar ratio of isoamyl alcohol to oleic acid was adjusted to $6: 1$, with a shaking rate of 200 $\mathrm{rpm}$. The measurements were conducted at a temperature of between 30 and $50{ }^{\circ} \mathrm{C}$ to follow the eventual changes at various temperatures. It would have been possible to carry out measurements at higher temperatures using the enzyme Novozym 435 or the ionic liquid [bmim] $\mathrm{PF}_{6}$, furthermore, changes over longer reaction times could be more suitable to follow and evaluate.

\subsection{Experiments using conventional heating}

Firstly, measurements under the conditions described in section 2.2 were conducted using conventional heating (Fig. 1). As can be seen esters were produced in high yields during the reactions in the ionic liquid as well as expected, and the yield was always higher in the ionic liquid at the same temperature.

\subsection{Experiments using microwave heating}

The results of the measurements using microwave irradiation are presented in Fig. 2. As can be observed, a much shorter time was necessary to reach equilibrium, and the reaction rate was also faster in the ionic liquid.

\subsection{Investigation of enzyme reuse}

The reusability of the enzyme Novozym 435 was studied under similar conditions in an ionic liquid (i.e. using conventional and microwave heating). The results indicated

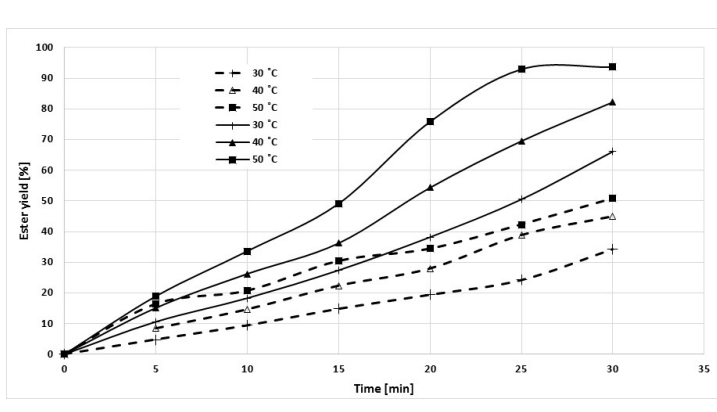

Figure 2: Biolubricant production in the organic solvent (dashed lines) and ionic liquid (solid lines) using microwave irradiation.

that the activity of the enzyme declined more rapidly using conventional heating.

\section{Discussion}

The results of the experiments conducted in the organic solvent, n-hexane, and in the ionic liquid, [bmim] $\mathrm{PF}_{6}$, under similar conditions provided a good basis to compare the effects of conventional and microwave heating during the production of biolubricants using enzymes since in both cases the same reaction volumes were used.

As can be seen in Fig. 1, the reaction rate was higher in the ionic liquid (IL) than in n-hexane (n-H), the organic solvent that was usually applied. The data in Table 1 can be further compared. By comparing the values of C, IL/C and $\mathrm{n}-\mathrm{H}$ (the ratio of enzyme activities in the ionic liquid and n-hexane using conventional (C) heating), it can be seen that the activity of the enzyme increased by a factor of 1.2 (on average) at each temperature due to the presence of the ionic liquid.

In the organic solvent the activity of the enzyme was found to be 2.8 times greater as a result of the microwave irradiation at each temperature (data of $\mathrm{MW}, \mathrm{n}-\mathrm{H} / \mathrm{C}, \mathrm{n}-\mathrm{H}$ ) compared to the conventional heating. In similar experiments in ionic liquids even more significant increases in the activity of enzymes were observed: microwave irradiation (MW) resulted in a 5.8-fold rise (data of MW, IL/C, IL).

A possible explanation for the significant increase is that the ionic liquid and microwave irradiation have a positive synergistic effect on the activity of the enzyme. Previously it was observed that ionic liquids seem to protect the enzyme in a similar way to the immobilising sup-

Table 1: Comparison of the activity of the enzyme under various conditions.

\begin{tabular}{|c|c|c|c|c|c|c|c|}
\hline \multirow[t]{2}{*}{$\mathrm{T} /{ }^{\circ} \mathrm{C}$} & \multicolumn{7}{|c|}{ Activity / $\mu \mathrm{mol} \cdot \mathrm{min}^{-1} \cdot \mathrm{g}^{-1}$} \\
\hline & Cony & al heating & Micrc & e heating & $\mathrm{C}, \mathrm{IL} / \mathrm{C}, \mathrm{n}-\mathrm{H}$ & $\mathrm{MW}, \mathrm{n}-\mathrm{H} / \mathrm{C}, \mathrm{n}-\mathrm{H}$ & MW, IL/C, IL \\
\hline & $\mathrm{n}-\mathrm{H}$ & IL & $\mathrm{n}-\mathrm{H}$ & IL & & & \\
\hline 30 & 162 & 194 & 475 & 1120 & 1.19 & 2.93 & 5.77 \\
\hline 40 & 342 & 444 & 990 & 2510 & 1.29 & 2.89 & 5.65 \\
\hline 50 & 575 & 660 & 1650 & 3840 & 1.15 & 2.86 & 5.82 \\
\hline
\end{tabular}




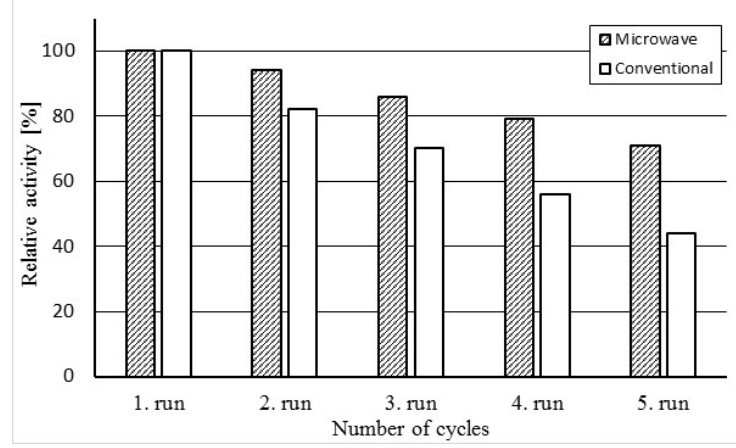

Figure 3: Reusability of the enzyme in the ionic liquid using microwave and conventional heating

port of the enzymes. In this work an immobilised enzyme was applied, thus, the synergistic effect simply strengthened the enzyme preparation or stabilised the active site of the enzyme. A similar effect has already been described in transesterification reactions in some papers in the literature $[18,20]$, but not with regard to esterification reactions.

The stabilisation effect of the ionic liquid was confirmed by the results presented in Fig. 3. By re-using the enzyme 5 times under conventional heating, the activity of the enzyme decreased much more rapidly than in the case of microwave heating. While in the first case $50 \%$ of the original activity of the enzyme was maintained after the fifth application, using microwave irradiation this value was $70 \%$.

\section{Conclusion}

The experiments led to a definite answer to the original question, namely whether microwave irradiation may enhance the effectivity of the enzymatic production of a biolubricant from isoamyl alcohol and oleic acid. It was observed that microwave heating increased the rate of reaction. During the evaluation of the experiments an unexpected effect was discovered: a synergistic effect was observed between microwave irradiation and the ionic liquid. As a result, a significantly greater increase in the activity of the enzyme was achieved during the reaction in the ionic liquid using microwave irradiation than in the organic solvent or according to the value obtained in the ionic liquid using conventional heating.

\section{Acknowledgement}

\section{REFERENCES}

[1] Carrea, G.; Riva, S.: Organic synthesis with enzymes in non-aqueous media (WILEY-VCH Verlag GmbH \& Co. KGaA, Weinheim, Germany) 2008 pp. 169-190 ISBN: 978-3-527-31846-9
[2] Salimon, J.; Salih, N.; Yousif, E.: Improvement of pour point and oxidative stability of synthetic ester basestocks for biolubricant applications, Arab J. Chem., 2012 5, 193-200 DOI: 10.1016/j.arabjc.2010.09.001

[3] Akerman, C.O.; Hagström, A.E.V.; Mollaahmad, M.A.; Karlsson, S.; Hatti-Kaul, R.: Biolubricant synthesis using immobilised lipase: Process optimisation of trimethylolpropane oleate production, Proc. Biochem., 2011 46, 2225-2231 DOI: 10.1016/j.procbio.2011.08.006

[4] Dossat, V.; Combes, D.; Marty, A.: Lipasecatalysed transesterification of high oleic sunflower oil, Enzyme Microb. Tech., 2002 30, 90-94 DOI: S0141-0229(01)00453-7

[5] Hajar, M.; Vahabzadeh, F.: Modeling the kinetics of biolubricant production from castor oil using Novozym 435 in a fluidized-bed reactor, Ind. Crop Prod., 2014 59, 252-259 DOI: org/10.1016/j.indcrop.2014.05.032

[6] Mobarak, H.M.; Mohamed, E.N.; Masjuki, H.H.; Kalam, M.A.; Al Mahmud, K.A.H.; Habibullah, M.; Ashraful, A.M.: The prospects of biolubricants as alternatives in automotive applications, Renew. Sust. Ener. Rev., 2014 33, 34-43 DOI: org/10.1016/j.rser.2014.01.062

[7] Su, L.; Hong, R.; Guo, X.; Wu, J.; Xia, Y.: Shortchain aliphatic ester synthesis using Thermobifida fusca cutinase, Food Chem., 2016 206, 131-136 DOI: 10.1016/j.foodchem.2016.03.051

[8] Cvjetko, M.; Vorkapic-Furac, J.; Znidarsic-Plazl, P.: Isoamyl acetate synthesis in imidazolium-based ionic liquids using packed bed enzyme microreactor, Proc. Biochem., 2012 47, 1344-1350 DOI: 10.1016/j.procbio.2012.04.028

[9] Atadashi, I.M.; Aroua, M.K.; Aziz, A.R.A.; Sulaiman, N.M.N.: Production of biodiesel using high free fatty acid feedstocks, Renew. Sust. Ener. Rev., 2012 16, 3275-3285 DOI: 10.1016/j.rser.2012.02.063

[10] Verma, P.; Sharma, M.P.: Review of process parameters for biodiesel production from different feedstocks, Renew. Sust. Ener. Rev., 2016 62, 1063-1071 DOI: $10.1016 /$ j.rser.2016.04.054

[11] Dörmó, N.; Bélafi-Bakó, K.; Bartha, L.; Ehrenstein, U.; Gubicza, L.: Manufacture of an environmentalsafe biolubricant from fusel oil by enzymatic esterification in solvent-free system, Biochem. Eng. J., 2004 21, 229-234 DOI: 10.1016/j.bej.2004.06.011

[12] Madarász, J.; Németh, D.; Bakos, J.; Gubicza, L.; Bakonyi, P.: Solvent-free enzymatic process for biolubricant production in continuous microfluidic reactor, J. Clean Prod., 2015 93, 140-144 DOI: 10.1016/j.jclepro.2015.01.028

[13] Bányai, T.; Bélafi-Bakó, K.; Nemestóthy, N.; Gubicza, L.: Biolubricant production in ionic liquids by enzymatic esterification, Hung. J. Ind. Chem., 2011 39(3), 395-399 
[14] Koszorz, Z.; Nemestóthy, N.; Ziobrowski, Z.; Bélafi-Bakó, K.; Krupiczka, R.: Influence of pervaporation process parameters on enzymatic catalyst deactivation, Desalination, 2004 162, 307-313 DOI: 10.1016/S0011-9164(04)00064-5

[15] Güvenc, A.; Kapucu, N.; Kapucu, H.; Aydogan, Ö.; Mehmetoglu, Ü.: Enzymatic esterification of isoamyl alcohol obtained from fusel oil: Optimization by response surface methodology, Enzyme Microb. Tech., 2007 40, 778-785 DOI: 10.1016/j.enzmictec.2006.06.010

[16] Vekariya, R.L.: A review of ionic liquids: Applications towards catalytic organic transformations, J. Mol. Liq., 2017 227, 44-60 DOI: 10.1016/j.molliq.2016.11.123

[17] Major, B.; Nemestóthy, N.; Bélafi-Bakó, K.; Gubicza, L.: Enzymatic esterification of lactic acid under microwave conditions in ionic liquids, Hung. J.
Ind. Chem., 2008 36, 77-81

[18] Yadav, G.D.; Pawar, S.P.: Synergism between microwave irradiation and enzyme catalysis in transesterification of ethyl-3-phenylpropanoate with nbutanol, Bioresource Technol., 2012 109, 1-6 DOI: 10.1016/j.biortech.2012.01.030

[19] Yu, D.; Wang, C.; Yin, Y.; Zhang, A.; Gao, G.; Fang, $\mathrm{X}$. : A synergistic effect of microwave irradiation and ionic liquids on enzyme-catalyzed biodiesel production, Green Chem., 2011 13, 1869-1875 DOI: $10.1039 / \mathrm{c} 1 \mathrm{gc} 15114 \mathrm{~b}$

[20] Kamble, M.P.; Chaudhari, S.A.; Singhal, R.S.; Yadav, G.D.: Synergism of microwave irradiation and enzyme catalysis in kinetic resolution of $(\mathrm{R}, \mathrm{S})-1$ phenylethanol by cutinase from novel isolate Fusarium ICT SAC1, Biochem. Eng. J., 2017 117, 121128 DOI: $10.1016 /$ j.bej.2016.09.007 